PROBLEMS OF NATIONAL PUBLIC AND PRIVATE LAW

DOI: 10.46340/eppd.2021.8.2.19

Tamara Yaroshevska, PhD in Law

ORCID ID: https://orcid.org/0000-0001-5525-1681

Dnipropetrovs'k State University of Internal Affairs, Ukraine

\title{
THE HISTORY OF FORMATION AND CURRENT \\ TRENDS OF DEVELOPMENT OF THE INVENTION IN UKRAINE
}

Тамара Ярошевська, к. ю. н.

Дніпропетровський державний університет внутрішніх справ, Україна

\section{ІСТОРІЯ СТАНОВЛЕННЯ ТА СУЧАСНІ ТЕНДЕНЦІї РОЗВИТКУ ВИНАХІДНИЦТВА В УКРАЇНІ}

The article considers the historical genesis of origin and development of legal protection systems of inventions in Ukraine. It is concluded that in the conditions of market economy formation and new forms of ownership its own legislation was developed in the field of invention for the first time in Ukraine, for the development and adoption of which a known scientific base was used and both international and domestic experience was applied. In general, the legislation of Ukraine in this area meets international norms and requirements of a market economy. Modern tendencies of invention development in Ukraine in the conditions of European integration are investigated. It is concluded that the recognition of biotechnology as one of the key technologies has become a global trend with which society associates the development of the pharmaceutical industry and the emergence of new methods of diagnosis and treatment of diseases. The analysis of the Ukrainian legislation reforms in the pharmaceutical branch is made. The article substantiates the expediency of establishing new strict criteria for the patentability of the utility model, the introduction of the "Bolar provision», the fight against "evergreen patents».

It is proved that updating the Ukrainian legislation in the field of invention contributes to the development of the national pharmaceutical industry, including the expansion of the range of drug production, and it will ensure a balance of interests between manufacturers of affordable drugs and their consumers. Attention is drawn to the growing worldwide challenge of overcoming the COVID-19 virus, which takes thousands of lives every day. It is concluded that Ukraine can complement this mission. It is noted that public policy should support the most important industries, in which the use of the latest advances in technology can ensure the greatest effect and return. Further ways to improve national legislation in the field of biotechnology are outlined. Keywords: industrial property, invention sphere, copyright certificate, patent, European integration, biotechnological inventions, pharmacological branch, medicines, «provisions of Bolar», COVID-19.

Постановка проблеми. Попри на досить грунтовне опрацювання історії становлення та розвитку інститутів права промислової власності, проте дослідження сучасних тенденцій розвитку винахідництва в Україні в умовах європейської інтеграції та оновлення законодавства у цій сфері $є$ малодосліджені.

Стан дослідження теми. Питанням генези інститутів охорони промислової власності присвячені праці таких відомих вчених, як А. І. Абдуллін, Г. О. Андрощук, О. В. Басай, Ю. Л. Бошицький, В. І. Єрьоменко, А. С. Довгерт, Р. Є. Еннан, В. М. Крижна, А. О. Кодинець, В. М. Коссак, Н. С. Кузнєцова, Р. А. Майданик, В. С. Макода, О. М. Мельник, О. П. Орлюк, О. А. Підопригора, О. О. Підопригора, Л. І. Ряботягова, О. Д. Святоцький, О. П. Сєргєєв, 
В. П. Скрипко, Р. Б. Шишка, О. С. Яворська, І. Є. Якубівський та ін. Роботи зазначених авторів заклали підгрунтя для поглиблення та інтеграції напрямів у сфері права промислової власності. Але наявні напрацювання не охоплюють усі питання правової охорони винаходів в Україні, зокрема в умовах євроінтеграції та оновлення законодавства у цій сфері.

Мета статті полягає у дослідженні історії становлення й сучасних тенденцій розвитку сфери винахідництва в Україні та внесення пропозицій і рекомендацій щодо вдосконалення національного законодавства у цій сфері.

Виклад основного матеріалу дослідження. Можна стверджувати, що винахідництво - одне 3 найдавніших занять людини й має вузько професійну сферу. Доцільно розглянути, як відбувалось становлення в Україні інституту права промислової власності взагалі та усфері винахідництва, зокрема. До 1991 року в УРСР, як і в усій колишній Радянській державі, через панування соціалістичної ідеології та суспільної форми власності, були відсутні спеціальні закони у сфері охорони промислової власності. Правове регулювання відносин у цій сфері забезпечувалося переважно підзаконними актами. Виключенням був розділ VI Цивільного кодексу Української РСР та Положення про відкриття, винаходи і раціоналізаторські пропозиції від 21 серпня 1973 року. Відповідно до норм цього Положення право на винахід належало винахіднику. Винахідник міг за своїм бажанням вимагати: по-перше, визнання за ним тільки авторства та отримання авторського свідоцтва і передачу державі виключного права на винахід; по-друге, визнання за ним авторства, надання йому виключного права на винахід та отримання патенту.

Відповідно до п. 31 цього Положення патент видавався на п’ятнадцятирічний строк. Отримати патент можливо було тільки у виключному порядку. Якщо винахідник таки ставав власником патенту, то впровадження винаходу було його особистою справою. Але на той час в основному на винахід видавались авторські свідоцтва. За повідомленнями В. Р. Скрипка ${ }^{1}$, попри те, що законодавством СРСР передбачалося дві форми охорони винаходу - авторське свідоцтво і патент, 99\% радянських громадян подавали заявки на видачу їм саме авторських свідоцтв, а не патентів. При цьому кількість патентів, що видавалися радянським винахідникам, з року в рік зменшувалася і становила буквально одиниці. Поряд з цим, збільшувалося число іноземних заявників, що патентували свої винаходи в СРСР. Цей факт зумовлював необхідність збереження в законодавстві Радянської держави такої форми правової охорони як патент. Проте, радянський винахідник як патентовласник не мав можливості організувати промислове застосування винаходу та інших об'єктів промислової власності, бо на той час засоби виробництва не могли знаходитися у приватній власності. Тому соціалістична держава через авторські свідоцтва налагоджувала відношення з винахідником. Держава виплачувала винагороду винахіднику та брала на себе турботу про реалізацію винаходу. Між тим, патентна форма таки існувала завдяки міжнародній політиці й становила інтерес тільки для іноземних винахідників.

Отже, авторське свідоцтво не один десяток років діяло в умовах соціалістичного господарства і на той час виправдовувало себе. Радянські підприємства безоплатно використовували винаходи, оскільки вони були державною власністю. Проте підприємства були зобов'язані виплачувати власнику авторського свідоцтва винагороду, яка була скоріше символічною. Але на той час винахідник наділявся низкою пільг і прав, які були досить вагомими й суттєвими. Не можна однозначно стверджувати, що це була малоефективна форма правової охорони об'єктів промислової власності. Вона була досить вигідна для самих винахідників: покладала турботу про використання винаходу на державу, наділяла винахідників низкою пільг, яких не мали й не мають сучасні володільці патентів. Серед пільг були, наприклад, право на фіксовану винагороду за використання винаходу, право на позачергове одержання квартири та інші. Але за роки існування Радянської держави протягом десятиріч формувалось уявлення про те, що тільки держава повинна дбати про впровадження нових наукових розробок у життя. У результаті такої практики в колишньому СРСР, у тому числі й в Україні, не було власника, зацікавленого в реалізації об'єктів промислової власності. Тому сприяли уніфіковані ціни на товари, уніфіковані товари та вилучення прибутку підприємств на користь держави.

Автор статті погоджується з О. О. Сімсон, О. Д. Святоцьким ${ }^{2}$, що тотальне одержавлення промислової власності у радянський період, присвоєння державою прав на використання результатів

\footnotetext{
${ }^{1}$ Скрипко, В. Р. (1982). Охрана прав изобретателей и рацчинализаторов. Москва: Наука.

${ }^{2}$ Святоцький, О. Д., Сімсон, О. Е. (2006). Реформування відносин власності у інтелектуальній сфері: правові проблеми. Право Украӥни, 2, 58-61.
} 
наукових розробок і досліджень, державне замовлення на науково-технічну продукцію та бюджетне фінансування призвели до повного відриву сектора науки від економіки та відсутності конкурентного ринкового середовища у сфері наукових та впроваджувальних організацій.

Спеціальне законодавство у сфері винахідництва в Україні почало формуватися після проголошення незалежності України. Тимчасове положення про правову охорону об'єктів промислової власності і раціоналізаторських пропозицій в Україні від 18 вересня 1992 року стало першим нормативно-правовим актом у сфері охорони прав на об'єкти промислової власності, який був прийнятий після легалізації приватної власності. Не дивлячись на те, що введення в дію цього Положення було тимчасовим заходом, даний нормативний акт став основою для створення правової бази у сфері промислової власності в Україні. Положенням 1992 р. була запроваджена єдина патентна форма охорони винаходів. Також, завдяки Положенню 1992 р. стало можливим в стислі строки організувати прийняття заяв і видачу патентів на винаходи та вирішити питання перереєстрації охоронних документів колишнього СРСР на території України.

Наступним кроком стало прийняття 15 грудня 1993 року Верховною Радою України Закону України «Про охорону прав на винаходи і корисні моделі». За цим Законом України, право на одержання патенту мали винахідник, роботодавець, правонаступник винахідника чи роботодавця та Фонд винаходів України, і це, на думку автора статті, було дуже доречно. Саме Фонд винаходів України мав здійснювати функції володільця майнових прав на патент від імені держави та в ії інтересах. Проте даний Фонд не був створений, до того ж у новій редакції цього самого Закону про нього взагалі не згадується. Таким чином, наша держава так і не створила практичного механізму реалізації свого права на винаходи.

У 1996 році відбулася видатна подія для всього українського народу - прийняття Конституції України. Конституція України чітко визначила принципові засади державної політики й у сфері інтелектуальної власності. Зокрема, ч. 1 ст. 41 Конституції України надала право володіти, користуватися і розпоряджатися своєю власністю, результатами своєї інтелектуальної, творчої діяльності. Статтею 54 Конституції України проголошено свободу наукової, науково-технічної, художньої та іншої творчості.

У червні 2000 року був прийнятий Закон України «Про внесення змін до Закону України «Про охорону прав на винаходи і корисні моделі». Але у новому законодавчому акті замість простого й чіткого режиму набуття та здійснення прав на винаходи (корисні моделі), який діяв раніше, було затверджено громіздку систему 3 шести різновидів патентів і для отримання кожного 3 яких установлено окремі правові підстави. Указом Президента України від 27 квітня 2001 р. «Про заходи щодо охорони інтелектуальної власності в Україні» були намічені шляхи до подальшого приведення національних норм у сфері промислової власності у відповідність до міжнародних норм.

Таким чином, за роки незалежності України були розроблені, прийняті й введені в дію основні законодавчі акти з питань охорони прав на об'єкти промислової власності взагалі, та на винаходи зокрема. Автор статті згодна з позицією відомих науковців сфери інтелектуальної власності О. Д. Святоцького та О. А. Підопригори ${ }^{1}$, що цими законодавчими актами була закладена основа системи правової охорони промислової власності в Україні. Проте, законодавство України у сфері промислової власності хронічно відставало від потреб часу і не забезпечувало охорону прав на об'єкти права промислової власності. У зв'язку з тим, виникла потреба перегляду національного законодавства i прийняття низки нових нормативних актів як на рівні поточного законодавства, так i на рівні кодифікованих актів. Тому, важливим законодавчим актом усфері інтелектуальної (промислової) власності став прийнятий 16 січня 2003 року Цивільний кодекс України (далі - ЦК України). Нині основним положенням ЦК України $є$ визнання майнових прав на результати інтелектуальної, творчої діяльності. На підставі ст. 421 ЦК України первинним суб'єктом інтелектуальної власності є творець об'єкта права. Відповідно до ст. 462 (ч. 1) ЦК України набуття права інтелектуальної власності на винаходи (корисні моделі) засвідчується патентом. Проте наразі ЦК України перебуває у стадії рекодифікації й головними чинниками сучасної рекодифікації ЦК України є: новітні реформи цивільного права в країнах $\mathrm{CC}$, зокрема, розробка і прийняття нових законодавчих актів, модернізація цивільно-правових кодифікацій з урахуванням міжнародних та європейських норм, європейська тенденція до гармонізації й уніфікації приватно-правового регулювання.

${ }^{1}$ Підопригора, О. А., Святоцький, О. Д. (2003). Основи правової охорони інтелектуальної власності в Україні. Київ: Ін-Юре. 
Міжнародне співробітництво у сфері охорони промислової власності має великий вплив на розвиток зовнішньої торгівлі, підприємництва, інвестиційні та інноваційні процеси в Україні. Міжнародний обмін науково-технічною й особливо патентною інформацією, новітніми технологіями сприяє розвитку науково-технічного потенціалу в Україні. Тому, після проголошення незалежності Україна заявила про подовження на ії території дії Паризької конвенції про охорону промислової власності, Договору про патентну кооперацію (РСТ) та приєдналася до основних міжнародних договорів у сфері охорони та захисту об' єктів права промислової власності. Також все більше визнання находять регіональні патентні союзи, як, наприклад, Європейська патентна конвенція. Йдеться про тенденцію зближення національних систем у сфері охорони прав на об'єкти промислової власності. Також у січні 1995 року набрала чинності Угода ТРІПС, яка $є$ одним 3 договорів Генеральної угоди з тарифів і торгівлі (ГАТТ) Світової організації торгівлі. Угода ТРІПС передбачає запровадження норм здійснення та охорони прав інтелектуальної власності; додержання міжнародних конвенцій з захисту прав інтелектуальної власності; надання режиму охорони державам найбільшого сприяння; надання національному режиму охорони. Україна стала повноправним членом світової спільноти й вступила до Світової організації торгівлі. 27 червня 2014 року Україна підписала Угоду про асоціацію між Україною- зоднієї сторони, та Європейським Союзом, Свропейським співтовариством з атомної енергії та їхніми державамичленами - з іншої сторони (далі - Угода про асоціацію України з СС). Подальші наміри України інтегруватись до ЄС. Для цього Україні потрібно вирішити чимало проблемних питань, одним 3 яких є формування в державі цивілізованого ринку промислової власності. Адже обраний Україною шлях інтеграції в СС потребує максимального наближення національного законодавства до законодавств країн-членів ЄС. Необхідно зазначити, що Угода про асоціацію України з СС містить значну кількість діючих у межах $Є С$ правових норм щодо охорони прав на об'єкти промислової власності, які мають бути імплементовані у законодавство України.

Таким чином, в умовах становлення ринкової економіки, нових форм власності в Україні вперше розроблено власне законодавство у сфері винахідництва, для розробки й прийняття якого була використана значна наукова база і застосований як міжнародний, так і вітчизняний досвід. В цілому, законодавство України у цій сфері відповідає міжнародним стандартам та вимогам ринкової економіки. Але стрімке зростання ролі винаходів в економічному розвитку суспільства, визнання творчої праці як найважливішого чинника успішного виробничого й комерційного функціонування сучасних високотехнологічних підприємств, підвищення їхньої конкурентоспроможності на внутрішньому та зовнішньому ринках спонукає до створення надійного та ефективного механізму правової охорони сфери винахідництва. Державна політика має підтримувати найбільш важливі галузі виробництва, в яких використання новітніх досягнень технік й технологій може забезпечити одержання найбільшого ефекту та віддачі ${ }^{1}$. Світовий досвід доводить, що ефективний механізм охорони прав на винаходи взагалі та, зокрема, на винаходи усфері біотехнології є важливим елементом економічної політики держави, спрямованої на прискорення науково-технічного прогресу й впровадження інновацій.

Визнання сфери біотехнології однією із ключових технологій стало світовою тенденцією, 3 якою суспільство пов'язує розвиток фармацевтичної галузі та появу нових методів діагностики та лікування захворювань. Безумовно, біотехнологічні винаходи $є$ результатом творчої праці людини та глибоких наукових досліджень, винахідницької діяльності й значних капіталовкладень, здійснюваних у складних лабораторіях.

В нашій державі давно назріла реформа у біотехнологічній сфері. Тому останнім часом було суттєво оновлене патентне законодавство України. Так, на підставі Закону України «Про внесення змін до деяких законодавчих актів щодо реформи патентного законодавства» у Закон України «Про охорону прав на винаходи та корисні моделі» були внесені значні позитивні зміни, завдяки яким нарешті був забезпечений вихід на ринок дійсно інноваційних лікарських засобів від виробників генеричних компаній і таким чином була обмежена фармацевтична монополія.

Запропоновано розглянути основні позитивні зміни у фармакологічній галузі.

1. Виробники лікарських засобів більше не зможуть отримувати охоронні документи на корисні моделі як речовини, в обхід перевірки критерію новизни. Бо відповідно до ст. 6 Закону України «Про

\footnotetext{
${ }^{1}$ Бошицький, Ю. Л. (2013). Проблеми права інтелектуальної власності. Часопис Київського університету права, 1, 213-214.
} 
охорону прав на винаходи та корисні моделі» об'єктом корисної моделі може бути лише пристрій або процес (спосіб). Отже, спеціальним законодавством у винахідницькій сфері встановлені нові суворі критерії охороноздатності корисної моделі, що говорить про безумовно позитивну та нову тенденцію у майбутньому, коли будуть отримувати патенти на дійсно інноваційні препарати.

2. Патентоволоділець на активний фармацевтичний інгредієнт лікарського засобу, більше не зможе розраховувати на автоматичне продовження строку чинності майнових прав на цей винахід. Наразі строк додаткової охорони не може перевищувати п'ять років, але буде засвідчуватиметься сертифікатом додаткової охорони, що залежить від фактичної тривалості процедури реєстрації лікарського засобу. Такі зміни були спрямовані на боротьбу з різного роду зловживаннями з боку володільців патентів, коли патентний захист на ті чи інші форми в $Є С$ давно минув, але в нашій державі він продовжує діяти. I таким чином стримується як розвиток фармацевтичної науки, так і доступність препаратів для українського населення.

3. В спеціальне законодавство у винахідницькій сфері імплементоване «положення Болар», необхідність якого давно обговорює фармацевтична спільнота. Таким чином, наразі генеричним компаніям надається можливість проводити розробки та дослідження без будь-яких обмежень в період дії патентного захисту на активний фармацевтичний інгредієнт. Однак зареєструвати свій продукт генерична компанія може отримати тільки на наступний день після закінчення строку дії патентного захисту на активний фармацевтичний інгредієнт або сертифіката додаткової охорони. Завдяки запровадженню «положення Болар» виробникам генеричних продуктів надається право на активізацію досліджень та розробок в період чинності патентів на основний інгредієнт.

Запровадження в Україні «положення Болар», по-перше, суттєво скоротить строк виходу генеричного продукту на ринок, бо виробники генеричних компаній зможуть вільно проходити державну реєстрацію на свій продукт. По-друге, знизить витрати із державного бюджету на закупівлю життєво необхідних ліків через наявність оптимальної цінової пропозиції серед українських виробників. По-третє, забезпечить баланс інтересів між виробниками ліків та їх споживачами. В цілому, зміни у національному патентному законодавстві сприятимуть розвитку національної фармацевтичної галузі, в тому числі розширенню номенклатури виробництва лікарських засобів ${ }^{1}$.

Нині у всьому світі найважливішим проблемним питанням $є$ виготовлення вакцини для подолання вірусу COVID-19, який кожен день забирає тисячі людських життів. Україна теж має долучитися до цієї місії. Так, у 2020 році Львівський Інститут біології клітини Національної академії наук України виграв грант на 10 мільйонів гривень від Національного фонду досліджень на розробку вакцини проти COVID-19. В Україні до цього часу подібних розробок не проводили. Але, як зазначають українські експерти й фахівці, шанси на створення готової для застосування вакцини в Україні не значні. Усе через відсутність обсягу необхідних інвестицій, практичного досвіду, потужну конкуренцію з боку досвідчених світових компаній, що спеціалізуються на виробництві імунобіологічних препаратів. Таким чином виникає питання: чи є у вітчизняних науковців шанси розробити необхідну вакцину, чи Україна буде традиційно закуповувати цю вакцину за кордоном, бо не має можливості створити власну? Автор статті вважає, що в Україні теж є потужній науковий потенціал, і науковці розроблятимуть вакцину за інноваційною технологією. 3 цього питання українські фахівці зазначили, що Україна також може розробляти вакцини й для цього $є$ відповідні наукові установи. Свого часу в нашій державі була і власна розробка, і власне виробництво імунобіологічних препаратів. Проте, криза в українській економіці, зменшення фінансування вітчизняної науки та незацікавленість держави призвели до зниження комерційного інтересу щодо проведення фундаментальних наукових досліджень та можливостей науковців належним чином використовувати об'єкти права промислової власності в Україні ${ }^{2}$.

Отже, можна зробити висновок, що, по-перше, в умовах становлення ринкової економіки, нових форм власності в Україні вперше розроблено власне законодавство у сфері винахідництва, для розробки й прийняття якого була використана значна наукова база і застосований як міжнародний,

\footnotetext{
${ }^{1}$ Ярошевська, Т. В., Стеценко, К. О. (2020). Реформа патентного законодавства України у сфері охорони прав на біотехнологічні винаходи. Цивільне право і прочес: витоки, здобутки і перспективи розвитку: матеріали Міжнарод. наук.-практ. конф. (Київ, 18-19 грудня 2020 р.) Київ, 139-143.

2 Барбу, С., Клименко, С. (2020). Ліки від короновірусу: де розробляють вакцину та чи може Україна собі це дозволити. Час. Підсумки тижня <https://www.5.ua/suspilstvo/liky-vid-koronavirusu-de-rozrobliaiut-vaktsynu-tachy-mozhe-ukraina-sobi-tse-dozvolyty-225788.html> (2020, грудень, 15).
} 
так і вітчизняний досвід. В цілому, законодавство України у цій сфері відповідає міжнародним нормам та вимогам ринкової економіки. По-друге, обраний Україною шлях інтеграції в СС потребує максимального наближення законодавства України до законодавств країн-членів СС. Необхідно зазначити, що Угода про асоціацію України з ЄС містить значну кількість діючих у межах ЄС правових норм щодо охорони інтелектуальної та, зокрема, промислової власності, які мають бути імплементовані у законодавство України. Це дозволить визначити конкретні заходи, які сприятимуть вступу України в ЄС. По-третє, державна політика має підтримувати найбільш важливі галузі виробництва, в яких використання новітніх досягнень технік й технологій може забезпечити одержання найбільшого ефекту та віддачі. По-четверте, держава повинна бути зацікавлена в розвитку такої важливої сфери як біотехнологія. Адже нині в Україні існує реальна потреба в розвитку та правовій охороні винаходів у сфері біотехнології не тільки в інтересах винахідників та їх сприянню технічному прогресу.

\section{References:}

1. Skripko, V. R. (1982). Ohrana prav izobretatelej i racionalizatorov [Protection of the rights of inventors and innovators]. Moscow: Nauka. [in Russian].

2. Sviatotskyi, O. D., Simson, O. E. (2006). Reformuvannia vidnosyn vlasnosti u intelektualnii sferi: pravovi problem [Property relations reforming in the intellectual sphere: legal issues]. Pravo Ukrainy [Law of Ukraine], 2, 58-61. [in Ukrainian].

3. Pidopryhora, O. A., Sviatotskyi, O. D. (2003). Osnovy pravovoi okhorony intelektualnoi vlasnosti v Ukraini [Fundamentals of legal protection of intellectual property in Ukraine]. Kyiv: In-Iure. [in Ukrainian].

4. Boshytskyi, Yu. L. (2013). Problemy prava intelektualnoi vlasnosti [Problems of intellectual property law]. Chasopys Kyivskoho universytetu prava [Journal of Kyiv University of Law], 1, 213-214. [in Ukrainian].

5. Yaroshevska, T. V., Stetsenko, K. O. (2020). Reforma patentnoho zakonodavstva Ukrainy u sferi okhorony prav na biotekhnolohichni vynakhody [Reform of the patent legislation of Ukraine in the field of protection of rights to biotechnological inventions]. Tsyvilne pravo i protses: vytoky, zdobutky i perspektyvy rozvytku: materialy Mizhnarodnoï naukovo-praktichnoï konferenciï (Kyiv, 18-19 hrudnia 2020 r.) [Civil law and process: origins, achievements and prospects of development: materials of the International Scientific and Practical Conference (December 18-19, 2020, Kyiv)], 139-143. [in Ukrainian].

6. Barbu, S., Klymenko, S. (2020). Liky vid koronovirusu: de rozrobliaiut vaktsynu ta chy mozhe Ukraina sobi tse dozvolyty [Coronavirus drugs: where the vaccine is being developed and whether Ukraine can afford it]. Chas. Pidsumky tyzhnia [Time. Results of the week] <https://www.5.ua/suspilstvo/liky-vid-koronavirusu-de-rozrobliaiutvaktsynu-ta-chy-mozhe-ukraina-sobi-tse-dozvolyty-225788.html> (2020, December, 15). [in Ukrainian]. 